\title{
THE ANALYSIS OF INTERNET MARKETING RESEARCH DIRECTIONS
}

The sustainable development of internet marketing (later identified as IM) faces the dynamic environment and its alterations, which occurs in both - business terms and conditions, and in the use of electronic tools and applicable concepts. The growing importance of the IM is being indicated by the development of electronic markets, increasing number of new generation consumers, deepening interest of scientists from different scientific fields, as well as widening the related knowledge base. Despite the continuously increasing amount of scientific literature about marketing on the internet, this area of research is still in its initial stage. The aim of this article is to analyse fields of ongoing IM researches and to identify areas for deeper examination. The following methods were used: the comparative analysis and summary of the scientific literature, information comparing, grouping and graphic information visualization techniques.

Keywords: internet marketing, internet marketing environment, communication, internet marketing research areas.

Statement of the problem in general form and it's connection with important scientific or practical tasks. The information revolution which is developing in a fast pace has a considerable impact on the economy. A majority of conventional business processes are being transferred into the virtual environment (one of them marketing activities), new forms of businesses are emerging and the range of means of communication with customers in virtual space is growing as well. According to the data provided by the Internet World Stat 2015 , the number of active users of the internet has grown from 360,985,492 (2000) up to $3,270,490,584$ (2015) within the last decade, the growth rate being $806 \%$. It is noteworthy that the number of users of the Internet has grown almost 9 times in 15 years and therefore the availability of the valid information and a systematic outlook of the current situation are required for timely decisions of the internet marketing (IM). Such a considerable growth of the number of the internet users is one of the indicators of the need for scientific studies in this particular field. Another notable aspect is the new generation of the Internet users (Generation Z) who see the internet as an integral part of their daily lives (e.g. such users are searching for the information using the internet systems only, but their search behaviour differs from other generations, also constantly growing and expanding social networks, blogs and virtual communities are major platforms for their self-expression) $[1,2]$. The researchers in this field should pay more attention as the digital content, including the social media, is 
being widely used in everyday life and has an undeniable impact on consumers $[1,3]$. This is the main reason why it is of particular importance for the companies to make proper use of the opportunities available in the virtual space. This is confirmed by the researches done by Tiago et al. [4] where it was found that the information concerning the developments in the field of marketing caused by the advancement of technology is fundamental for the players in the field of marketing, as it leads to emergence of new brands, markets, market leaders, channels and marketing tools.

The above-mentioned factors in the development of the IM such as the IT development and the rising numbers of the e-consumers lead to the advancements in new fields of science, calling for new evaluation methods in turn. The aim of the article is to analyse the current studies in the field of the IM, identifying the fields where more in-depth research are needed. The methods of research used in the article were the analysis and summarising of scientific literature, the methods of comparison, grouping and visual display of the information have been used in the analysis.

Analysis of the latest research and publications, which initiated the solution of this problem and on which the author relies. Although the e-market is rather new, it is growing extremely rapid and offering new possibilities for both, businesses and consumers. The history of the IM goes back to the first e-mail sent in 1971 [5], when US programmer Raymond Samuel Tomlinson developed the first email application for the Advanced Research Projects Agency Network (ARPANET), consisting of a program called SNDMSG for sending the mail, and a program called READMAIL for reading the mail. Thus, the primary purpose of the IM is described as communication and digital information interchange. The First IM Conference was one of the earliest worldwide events held in 1994 in San Fransico and was dedicated to the problems and development directions of the IM. At the conference the predecessors of the e-marketing M. Andreesen, K. McCarthy, C. «Buz» Buszko and others draw attention to the increasing potential of the new market to reach the consumers and the use of new interactive ways for improvement of the communication process. Marc Andreessen anticipated that applications will be successful in the next 5 or 10 years and those are the applications that tie people together.

A great variety of concepts is being used in the contemporary scholarly literature to define the concept of the IT-based marketing: interactive marketing, digital marketing, IM, emarketing, virtual marketing, cyber marketing. Some authors defining internet marketing are emphasizing the communication in the electronic space, management of relations with customers, transactions and distribution in the e-space, whereas others are using the concept e-marketing and highlighting the following key emphases of the definitions: transactions, distributions in the e-space, management of relations with customers, use of the internet for the marketing purposes. Business dictionary defines cyber marketing as the communication process in the e-space. The analysis leads to a conclusion that the different concepts found in the scholarly literature are used to describe basically the same process. It should be noted that authors are putting an emphasis in definitions on the different dimensions, such as: communication, management of relations with customers, transactions, distributions in the espace and use of the Internet for the marketing purposes. The following definition will be used further in the article: the IM means the application of information technologies in the interaction with the customers' process in the virtual environment for the organisation's marketing purposes. After defining the concept of the IM, the fundamental dimensions have been identified which will be paid attention to in the analysis of the fields of study of the IM.

When analysing IM, it is important to determine the right context, which could be assessed in both micro and macro levels. On macro level IM is attractive because of the possibility of using an increasingly greater number of specific marketing tools for making and 
keeping close connections with consumers. Macro level also includes the focus on the segment marketing, resulting from the development of the IT and the Internet, when the mass marketing tools are being replaced by marketing focused on a specific customer or a group of customers. It is also important to emphasize the emergence of the personalisation, in addition to emergence of two other aspects: information and interactivity. Meanwhile on the micro level the following advantages have been found:

1. significant savings of business resources;

2. possibility of customer segmentation;

3. possibility of efficiency fixation (conversion into sales, payment based on the consumer reaction - a payment is executed after clicking, opening by the consumer, etc.);

4. application of the dialog principle (a possibility of having a direct contact with a customer affected by previous marketing elements);

5. global nature of the IM (a possibility of reaching a worldwide consumer).

Definition of IM concept allowed to set the basic dimensions, which will be reflected on in the IM field investigations. The IM environments will be evaluated further in the research and all the fields of research found will be analysed in the light of the three channels, defined by Kiang et al [6]:

- communication channel - the exchange of the information between the seller and the buyer (providing access to the information, tools for information management and transfer, aiming to increase the interactivity and conceivable experience; for the purpose of collecting the information concerning the customers by means of opinion polls and various contests for research and development of new products, establishment of relations and adapting for personal needs;

- transaction channel - sales activity (aiming to improve the visibility and reach of a wider consumer base, increase of income and revenue by exploiting the possibilities of cross sales, implementing simplification of the transaction process for reduction difficulty of tasks, reducing costs of document management and transactions; personalizing the advertising and sales to individual customers and improving flexibility);

- distribution channel - for physical exchange with goods and services: aiming to avoid extensive stock keeping costs, costs of utility services and the rent of facilities, etc.; in order to shorten the supply chain and reduce the commission and operational costs.

The classification of the IM channels provided by Shi Kiang et al. [7] reveals the nature of IM processes, however, considering the results of the completed analysis of the concepts of the IM, it was found that an additional channel of management of relations with consumers should be distinguished. Therefore, the IM will be analysed on the basis of 4 basic channels further in the study (management of communication, transactions, distribution and relations with customers).

Aiming to identify the fields where more in-depth research is needed, an analysis of IM studies on the evolution topic has been carried out. Therefore, it was noticed that extremely in-depth studies in this field have been carried out by Ngai [8], Schibrowsky, Peltier, Nill [9], Taylor, Strutton [3].

Ngai [8] was one of the first to classify the IM studies from 1987 until 2000. Later on, these studies have been supplemented by Schibrowsky, Peltier, Nill [9] who have analysed the evolution of the IM research, by grouping the IM studies of the period 2001 to 2004 . Moreover, Taylor and Strutton [3] have completed the synthesis of the sources of the literature concerning the marketing and information systems, published from 1996 until 2007 and have made general conclusions regarding the findings in the area of the nature of primary consumer behaviour and influence on an e-consumer. As a result of dynamic developments in 
this field, there is a need to expand on the existing studies by conducting systematic analyses of the newly emerging aspects and their impact on the currently existing fields of research.

Some drastic changes have been observed in the field of the IM research. According to the studies of Ngai[8], the publications of the results of IM studies have considerably risen in number since 1996. The study of the IM fields, concerning the period 1987 to 2000, has shown that 19 articles had been published annually; the greatest increase was observed in the year 1998 to 1999 (64 publications). Meanwhile, in 2001 to 2004, the average annual number of publications rose up to 639 articles [9]. The study carried out by the authors of this article has shown that, in the period 2004 to 2013, the average annual number of scientific publications on the topic of the IM was 7174 . Hence, it can be concluded that the importance of the IM and the focus on this field of research has risen by more than 10 times. The peak growth was observed in 2012 to 2013 . The comprehensive analysis of the current situation requires a detailed analysis of the completed studies in this field and the methods of research applied therein:

1. Ngai [8] has completed a systemic analysis of the marketing studies using the grouping based on 5 categories, which was introduced by Leonard (2001) (IM functions, IM environment, specific application of IM, IM studies, etc.) and distinguishing even smaller elements in each of the categories (a total of 21 directions of research on the IM).

2. Schibrowsky et al. [9] have distinguished 10 basic groups (consumer behaviour, B2B, strategy, communication, product/brand, pricing, aspects of research, political, legal aspects, education and distribution) and provided a classifier including 44 second-level elements.

3. Taylor and Strutton [3], who have been studying consumer behaviour aspects in the IM research, have distinguished 6 basic groups (consumer behaviour, IM strategy, financial/legal aspects, pricing, distribution, impact of feedback, viral marketing); afterwards, after more in-depth research, they have presented a system of grouping to 3 second-level groups (user perception of online retail attributes, pre-purchase user attitudes, and postpurchase users attitudes) and 8 third-level elements of the consumer behaviour classification (Table 1).

The need for more in-depth studies was found after the completion of the analysis of the classification of new directions of research, predetermined by the development of the information technologies, as proposed by Ngai [8], Schibrowsky, Peltier ir Nill [9] and Taylor, Strutton [3]. Therefore, it is beneficial to discuss the development in detail, according to the chronology of the development of the fields of research.

The major fields of research included functions of the IM and its generic studies at its initial stage from 1987 to 2000.

The first studies of IM created the basis for further directions of research. The functions of the IM were the focal point of the research in the period 1987 to 2000, which allowed to define basic possibilities offered by the IM. The most in-depth studies within the IM environment group have been carried out in the field of the consumer behaviour. In the initial stage of the research, 1995 to 2000 , the consumer behaviour has been attributed to the environment of the IM [8], whereas in the later period 1995 to 2004 [9] the consumer behaviour has been distinguished as a separate group, with the attributable categories, what indicates the growing need for the consumer behaviour studies. It was determined that in the period 2000 to 2009 [3] the consumer behaviour was one of the key fields of the IM research. As a result, 3 groups of factors have been identified in this field. They have been broken down into: user perception of online retail attributes, pre-purchase user attitudes, and post-purchase users' attitudes. 8 fields of basic research in the following groups of factors (usefulness, 
aspects of ease of use, value, risk, trust, concern with privacy, internet attraction and satisfaction) have been identified.

Table 1 - Classification of the fields of the IM research (compiled by the authors)

\begin{tabular}{|c|c|c|c|c|c|c|c|c|c|}
\hline Author, & \multicolumn{9}{|c|}{ Classification of the IM research } \\
\hline 1 & 2 & 3 & 4 & 5 & 6 & 7 & 8 & 9 & 10 \\
\hline \multirow[b]{2}{*}{ 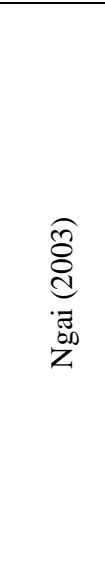 } & $\begin{array}{c}I M \\
\text { functions }\end{array}$ & $\begin{array}{c}\text { IM } \\
\text { environment }\end{array}$ & $\begin{array}{c}\text { Specific } \\
\text { application of } \\
\text { the IM }\end{array}$ & IM research & Other & & & & \\
\hline & $\begin{array}{l}\text { Management, } \\
\text { planning and } \\
\text { strategy } \\
\text { Trade } \\
\text { Distribution } \\
\text { channels } \\
\text { Market structure } \\
\text { Physical } \\
\text { distribution } \\
\text { Pricing } \\
\text { Product } \\
\text { Sales promotion } \\
\text { Advertising } \\
\text { Sales } \\
\text { Management }\end{array}$ & $\begin{array}{l}\text { Consumer } \\
\text { behaviour } \\
\text { Legal, } \\
\text { political and } \\
\text { economic } \\
\text { aspects } \\
\text { Ethics and } \\
\text { social } \\
\text { responsibility }\end{array}$ & $\begin{array}{l}\text { Industrial } \\
\text { International- } \\
\text { level and } \\
\text { comparative } \\
\text { Services }\end{array}$ & $\begin{array}{l}\text { Science theory } \\
\text { and philosophy } \\
\text { Methodology of } \\
\text { research } \\
\text { Information } \\
\text { technology }\end{array}$ & $\begin{array}{l}\text { Educational } \\
\text { and profes- } \\
\text { sional } \\
\text { aspects } \\
\text { Generic IM }\end{array}$ & & & & \\
\hline \multirow[b]{2}{*}{ 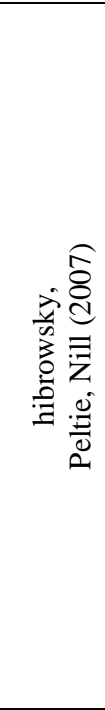 } & $\begin{array}{l}\text { Consumer } \\
\text { behaviour }\end{array}$ & $\begin{array}{c}\text { Business to } \\
\text { business } \\
(B 2 B)\end{array}$ & Strategy & Communication & $\begin{array}{l}\text { Product/ } \\
\text { brand }\end{array}$ & Pricing & $\begin{array}{l}\text { Research } \\
\text { aspects }\end{array}$ & $\begin{array}{c}\text { Poli- } \\
\text { tical/ } \\
\text { legal } \\
\text { as- } \\
\text { pects }\end{array}$ & Education \\
\hline & $\begin{array}{l}\text { Cognitive } \\
\text { aspects } \\
\text { Consumer } \\
\text { demographics } \\
\text { Intercultural / } \\
\text { national issues } \\
\text { Aspects of } \\
\text { consumers' } \\
\text { online search } \\
\text { Motivation } \\
\text { Virtual } \\
\text { communities } \\
\text { Satisfaction } \\
\text { Internet } \\
\text { segmentation } \\
\text { Reliability } \\
\text { Usage }\end{array}$ & $\begin{array}{l}\begin{array}{l}\text { Delivery } \\
\text { chain }\end{array} \\
\begin{array}{l}\text { Business } \\
\text { communicati } \\
\text { on }\end{array} \\
\text { Sales } \\
\text { management } \\
\text { Business } \\
\text { relations }\end{array}$ & $\begin{array}{l}\text { Strategy } \\
\text { Relationship } \\
\text { management } \\
\text { Reputation } \\
\text { Target } \\
\text { markets } \\
\text { International } \\
\text { marketing } \\
\text { Profit } \\
\text { Competition / } \\
\text { competitive } \\
\text { advantage } \\
\text { Best practices } \\
\text { Services }\end{array}$ & $\begin{array}{l}\text { Communication } \\
\text { efficiency } \\
\text { Integrated } \\
\text { marketing } \\
\text { communication } \\
\text { Presentation / } \\
\text { creation of the } \\
\text { information } \\
\text { E-mail } \\
\text { Website } \\
\text { visibility } \\
\text { Banner } \\
\text { advertising }\end{array}$ & 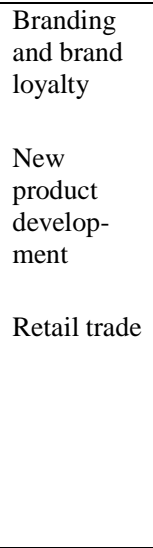 & $\begin{array}{l}\text { Auctions } \\
\text { Pricing } \\
\text { aspects }\end{array}$ & $\begin{array}{l}\text { Secon-dary } \\
\text { data } \\
\text { Collection } \\
\text { of } \\
\text { e-data } \\
\text { Aspects of } \\
\text { e-research. }\end{array}$ & $\begin{array}{l}\text { Ethics } \\
\text { Fraud } \\
\text { Law } \\
\text { Priva- } \\
\text { cy } \\
\text { Tax } \\
\text { as- } \\
\text { pects }\end{array}$ & \\
\hline \multirow{3}{*}{ 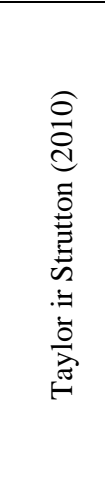 } & $\begin{array}{l}\text { Consumer } \\
\text { behaviour }\end{array}$ & \multirow[t]{3}{*}{ IM strategy } & \multirow[t]{3}{*}{$\begin{array}{l}\text { Financial/ } \\
\text { legal aspects }\end{array}$} & \multirow[t]{3}{*}{ Pricing } & \multirow[t]{3}{*}{ Distribution } & \multirow{3}{*}{$\begin{array}{c}\text { Impact of } \\
\text { feedback, } \\
\text { viral } \\
\text { marke- } \\
\text { ting }\end{array}$} & \multicolumn{3}{|c|}{$\begin{array}{c}\text { Categorisation of the fields of } \\
\text { consumer behaviour }\end{array}$} \\
\hline & $\begin{array}{l}\text { Search for the } \\
\text { information } \\
\text { Decision- } \\
\text { making, privacy } \\
\text { and reliability } \\
\text { Human imaging }\end{array}$ & & & & & & \begin{tabular}{l|} 
user \\
percep- \\
tion of \\
online \\
retail \\
attributes
\end{tabular} & $\begin{array}{l}\text { pre- } \\
\text { purchase } \\
\text { user } \\
\text { attitudes }\end{array}$ & $\begin{array}{l}\text { post- } \\
\text { pur- } \\
\text { chase } \\
\text { users } \\
\text { at- } \\
\text { titudes }\end{array}$ \\
\hline & $\begin{array}{l}\text { using computer } \\
\text { graphics }\end{array}$ & & & & & & $\begin{array}{l}\text { Utility } \\
\text { Easiness } \\
\text { of use } \\
\text { Value } \\
\text { Risk }\end{array}$ & $\begin{array}{l}\text { Confi- } \\
\text { dence } \\
\text { Privacy } \\
\text { concern } \\
\text { Internet } \\
\text { attract- } \\
\text { tion }\end{array}$ & $\begin{array}{l}\text { Satisfac } \\
\text { tion }\end{array}$ \\
\hline
\end{tabular}


The studies in the field of strategy have been attributed to the IM environment by Ngai [8] whereas these studies have been attributed to a separate field of research by Schibrowsky et al.[9], which includes relationship management, reputation, target markets, profit, research of the competitive advantage, analysis of the best practices and service research. Currently the studies in the field of the IM strategy are of high importance due to great numbers of newly emerging IM tools, what leads to changes in the IM strategy. The growing interest of the business sector in the possibilities offered by the IM is shown by a separate field of research B2B [9], including a part of the functions mentioned by Ngai [8]) (delivery chain, sales management) as well as the new fields of research meant for the business communication (business communication, business relations).

The growing use of the IM is demonstrated by the emergence of the following new fields in 1997, which require more in-depth studies: political, legal aspects that are identified by Schibrowsky et al. [9]. With the growing use of the IM, consequently there is a need for legal regulations concerning the aspects of taxes, privacy and researching potential frauds in the e-space in parallel. Meanwhile, the legal and political aspects had been attributed to the studies in the field of IM environment by Ngai [8] in the period 1995 to 2000. The studies in these fields are of particular importance for further successful development of the IM as the failure of the legal regulation to adapt to the existing and potential information technologies is often one of the factors hindering the IM development the most.

The IM offers new possibilities for the product development process. The need for studies of product and branding is highlighted by Schibrowsky et al. [9], who have identified a separate group in their study. Several aspects are assigned to the group: loyalty, new product and retail trade. It can be concluded that at the time when the studies in the field of the product had been attributed to the research of the IM functions by Ngai [8] and when the studies in that field have accounted for merely $2.8 \%$ of the studies of the group of functions the studies in the field of products have not been of particular relevance in the stage of 1995 to 2000. The lack of relevance of the research stems from the fact that in the initial stage of the IM the possibilities of personalisation had not been well-developed, which would allow for creation of the product best satisfying the customer's needs.

Taylor and Strutton [3] focused on the aspects of internet purchases, defined the fields of preconception, preconditions for purchase and purchase assessment. The newly emerged fields of the IM research include the aspects of the ease of use, post-purchase satisfaction. The emergence and relevance of the studies in these fields is affected by the fact that the new generation (Generation $\mathrm{Z}$ ) consumers are adapting to the new technologies extremely fast, their conception of the electronic commerce and the related aspects is rapidly changing.

It can be concluded that in the first stage (1989 to 2000) the scholars have been researching the functions of the IM, the IM environment, fields of application and analysed the possible studies in the field. In the second stage (1995 to 2004) the greater focus was on the research of consumer behaviour, research of strategy formation, political-legal factors, product and B2B communication. In 2000 to 2009, the focus was on the particularly relevant research of consumer behaviour factors of consumer decision-making in the e-environment. In the advancement of the information technologies, new IM tools emerge as well as the needs of consumers in the e-environment are also changing. The IM research allows adapting to them. All this leads to the emergence of new fields of the IM research.

Highlighting the previously unresolved parts of the general problem to which the article is devoted. Despite the numerous researches in this subject area, there were identified and analyzed main stages of the internet marketing past research directions, but internet marketing keeps developing, emerging new technologies and customer preferences, and there is a lack of the nowdays relevant internet marketing research areas identification. 
Formulation of the purpose of the article (statement of the problem). To analyze the relevance of the changes in the internet marketing fields over the time and identification of the need for research development.

Statement of the main material of the research with full justification of the scientific results obtained. Upon analysing the relevance of the changes in the IM fields over the time and identification of the need for research development. Authors of the article carried out the research of the IM fields which are currently relevant. The aim of the research is to analyse the fields of research of the IM carried out from 2004 to 2013 and to identify the new directions requiring more in-depth research. The main objectives of this study have been acknowledged:

1. To identify the fields of the IM research from 2004 to 2013;

2. To present the most important dimensions of the IM fields of research;

3. To identify the directions requiring more in-depth research.

Web marketing is difficult to be assigned to a single field of science - achievements and discoveries are published in databases of different fields, such as information technology and information systems, economics, business and management, marketing, communication and innovation.

Currently, the number of scientific journals and databases, where the articles about the IM are published, has increased significantly, therefore it is important to clearly define the scope and the methodology of the research. In the first stage, an electronic database is chosen for the analysis of the research. The main criteria for choosing are:

1. There must be full-scale articles submitted in the electronic database;

2. In order to ensure the reliability of the data, the articles submitted in the database must be peer-reviewed;

3. The database must include a wide range of number of journals in the IM field;

4. The function of the search system of the database are to be sorted by relevance.

In the light of the criteria mentioned, the database ScienceDirect has been chosen as the primary for the research. The fundamental principle of an electronic successful search of data is the time limits formulated properly [9], therefore the search of the publications of the IM studies was carried out on the basis of the keyword method. The keywords set out: IM, electronic/e-marketing and web marketing/virtual marketing. The selected search period is from 2004 to 2013.

The sample size was $n=150$ of the publications on the topic of the IM (probability $95 \%$, margin of error $8 \%$, size of the general population 71738 (a set of publications by 4 keywords of interest published in Science Direct database). For the purpose of obtaining reliable characteristics of the general population, the stratified sample is used, assuming that the fields of research of the IM should be sufficiently homogeneous in each stratum. The sample size is distributed among $L$ strata $(L-$ the number of strata, in this case stratum means 1 search by the keyword method, $L=4$ ), therefore $n=n_{1}+n_{2}+n_{L}$, where each $n_{i}$ is determined by the following formula:

$$
n_{i}=n\left(\frac{N_{i}}{N}\right)
$$

where $\boldsymbol{N}_{\boldsymbol{i}}$ is the number of units of publications in stratum i.

The stratified sample sizes calculated using the said formula are listed in Table 2 
Table 2 - The results of the search by the keyword method

\begin{tabular}{|l|c|c|c|c|}
\hline \multicolumn{1}{|c|}{ Keyword } & $\begin{array}{c}\text { Stratum } \\
L_{i}\end{array}$ & $\begin{array}{c}\text { Total result of research } \\
\text { of interest (publications } \\
\text { in journals) }\end{array}$ & $\begin{array}{c}\text { Other result of research } \\
\text { (publications in books) }\end{array}$ & $\begin{array}{c}\text { Stratified sample } \\
\text { size } \\
n_{1}\end{array}$ \\
\hline \multicolumn{1}{|c|}{2} & 2 & 21148 & 4 & 5 \\
\hline $\begin{array}{l}\text { Internet } \\
\text { Marketing }\end{array}$ & $L_{1}$ & 19733 & 146 & 44 \\
\hline $\begin{array}{l}\text { Electronic } \\
\text { Marketing }\end{array}$ & $L_{2}$ & 8412 & 187 & 41 \\
\hline Web marketing & $L_{3}$ & 22445 & 69 & 47 \\
\hline $\begin{array}{l}\text { Virtual } \\
\text { marketing }\end{array}$ & $L_{4}$ & & & 18 \\
\hline
\end{tabular}

The number $n_{i}$ of the publications presented the first in each search conducted by the keyword method was selected according to the criterion of relevance to the keywords. The articles published in the English language have been selected, the summaries of the articles have been analyzed, in order to select the publications, the key aspect of which is the research in the field of the IM and which belong to the pre-determined disciplines. This stage of the research allowed to select 128 publications. Upon the change of the sample size during the procedure of the research, the margin of error has been adjusted, which has increased by $0.48 \%$ and accounts for $8.48 \%$. The data of the individual publications is prepared for the further grouping analysis.

As a result of the completed analysis of scientific publications, the studies in the field of the IM have been grouped into 43 categories [10]: evolution of e-marketing, legal-social aspects, national traits of behavior of consumers / business in e-space, e-strategy, impact of the IM on the activities of an enterprise, efficiency of the marketing operations, the IM in various industries, impact of IM on the consumer behavior, social media, viral marketing, mobile marketing, impact of feedback, website visitor data analysis, personalization, researches of web page quality and design, element analysis, internet coupons, marketing tools, aspects of application of the e-tools, research of search systems, impact of the IT development on consumers, aspects of ecology in the e-marketing, privacy, blogs, technology management, aspects of segmentation, cognitive aspects, shopping habits, IM education, market structure, social commerce, management of the supply chain, advertising, pricing, B2B relationship management, content marketing, product, reliability, banners, reputation, virtual technological capabilities, electronic payments, sales channels.

The research showed that the scientists are working in different fields of the IM and are actively making studies on the object which is influenced by newly emerging technologies and changes in consumer behaviour which may result in the new fields of the IM researches. The research fields of feedback impact, viral marketing, and internet coupons have newly formed in this period. The fields of IM research were grouped by logical attribution into channels (Table 3), the interrelationship of which is shown in Figure 1. It could be stated, that the basic dimensions of the internet marketing are the following: technologies, tools, assessment of efficiency, consumer behaviour, models, e-strategy and environment. The dimensions identified exhibit the properties of transactions, distribution, communication and the channels of customer relationship management. 
Table 3 - Internet marketing channels and the fields of research

\begin{tabular}{|c|c|c|c|}
\hline Communication channel & Transaction channel & Distribution channel & $\begin{array}{c}\text { Relations with } \\
\text { customers channel }\end{array}$ \\
\hline 1 & 2 & 3 & 4 \\
\hline \multicolumn{4}{|l|}{ Social media } \\
\hline \multicolumn{4}{|l|}{ Virus marketing } \\
\hline $\begin{array}{l}\text { Legal-social } \\
\text { aspects }\end{array}$ & $\begin{array}{l}\text { Legal-social } \\
\text { aspects }\end{array}$ & $\begin{array}{l}\text { Legal-social } \\
\text { aspects }\end{array}$ & $\begin{array}{l}\text { Legal-social } \\
\text { aspects }\end{array}$ \\
\hline \multirow[t]{2}{*}{$\begin{array}{l}\text { National features of } \\
\text { consumer behaviour }\end{array}$} & $\begin{array}{l}\text { National features of } \\
\text { consumer behaviour }\end{array}$ & $\begin{array}{l}\text { National features of } \\
\text { consumer behaviour }\end{array}$ & $\begin{array}{l}\text { National features of } \\
\text { consumer behaviour }\end{array}$ \\
\hline & $\begin{array}{l}\text { National features } \\
\text { business in e. market } \\
\text { place }\end{array}$ & $\begin{array}{l}\text { National features } \\
\text { business in e. market } \\
\text { place }\end{array}$ & $\begin{array}{l}\text { National features } \\
\text { business in e. market } \\
\text { place }\end{array}$ \\
\hline Mobile marketing & Mobile marketing & Mobile marketing & \\
\hline Impact of feedback & & & Impact of feedback \\
\hline Users data analysis & Users data analysis & Users data analysis & Users data analysis \\
\hline \multicolumn{4}{|l|}{$\begin{array}{l}\text { Marketing } \\
\text { communication }\end{array}$} \\
\hline & $\begin{array}{l}\text { IM impact on company } \\
\text { performance }\end{array}$ & $\begin{array}{l}\text { IM impact on company } \\
\text { performance }\end{array}$ & $\begin{array}{l}\text { IM impact on company } \\
\text { performance }\end{array}$ \\
\hline \multicolumn{4}{|l|}{$\begin{array}{l}\text { IM impact on consumer } \\
\text { behaviour }\end{array}$} \\
\hline E. strategy & E. strategy & E. strategy & E. strategy \\
\hline \multicolumn{4}{|l|}{ Personalization } \\
\hline & $\begin{array}{l}\text { Marketing operations } \\
\text { performance } \\
\text { measurement }\end{array}$ & & $\begin{array}{l}\text { Marketing operations } \\
\text { performance } \\
\text { measurement }\end{array}$ \\
\hline \multicolumn{4}{|l|}{ Brand strategy } \\
\hline \multirow[t]{2}{*}{$\begin{array}{l}\text { Design of web site, } \\
\text { analysis of web site } \\
\text { elements }\end{array}$} & $\begin{array}{l}\text { Design of web site, } \\
\text { analysis of web site } \\
\text { elements }\end{array}$ & & \\
\hline & $\begin{array}{l}\text { Quality analysis of web } \\
\text { sites }\end{array}$ & & \\
\hline \multirow[t]{3}{*}{ Online coupons } & Online coupons & & Online coupons \\
\hline & Marketing tools & & \\
\hline & $\begin{array}{l}\text { Aspects of e. tools } \\
\text { implementation }\end{array}$ & & \\
\hline \multicolumn{4}{|l|}{$\begin{array}{l}\text { Analysis of search } \\
\text { system }\end{array}$} \\
\hline $\begin{array}{l}\text { Impact of IT on } \\
\text { customers }\end{array}$ & $\begin{array}{l}\text { Impact of IT on } \\
\text { customers }\end{array}$ & $\begin{array}{l}\text { Impact of IT on } \\
\text { customers }\end{array}$ & \\
\hline \multicolumn{4}{|l|}{$\begin{array}{l}\text { Aspects of ecology in } \\
\text { marketing }\end{array}$} \\
\hline IM in various industries & IM in various industries & IM in various industries & IM in various industries \\
\hline Privacy & Privacy & Privacy & Privacy \\
\hline
\end{tabular}


Continued Tab 3

\begin{tabular}{|c|c|c|c|}
\hline 1 & 2 & 3 & 4 \\
\hline & E. blogs & & \\
\hline $\begin{array}{l}\text { Evolution of e. } \\
\text { marketing }\end{array}$ & $\begin{array}{l}\text { Evolution of e. } \\
\text { marketing }\end{array}$ & $\begin{array}{l}\text { Evolution of e. } \\
\text { marketing }\end{array}$ & $\begin{array}{l}\text { Evolution of e. } \\
\text { marketing }\end{array}$ \\
\hline $\begin{array}{l}\text { Management of } \\
\text { technologies }\end{array}$ & $\begin{array}{l}\text { Management of } \\
\text { technologies }\end{array}$ & $\begin{array}{l}\text { Management of } \\
\text { technologies }\end{array}$ & $\begin{array}{l}\text { Management of } \\
\text { technologies }\end{array}$ \\
\hline \multicolumn{4}{|l|}{ Web addiction } \\
\hline \multicolumn{4}{|l|}{ Segmentation by gender } \\
\hline \multicolumn{4}{|l|}{ Cognitive aspects } \\
\hline \multicolumn{4}{|l|}{ Shopping behaviour } \\
\hline & IM education & & \\
\hline & Market structure & & \\
\hline & & Social commerce & Social commerce \\
\hline & & $\begin{array}{l}\text { Supply chain } \\
\text { management }\end{array}$ & $\begin{array}{l}\text { Supply chain } \\
\text { management }\end{array}$ \\
\hline Advertising & Advertising & & \\
\hline Pricing & Pricing & & \\
\hline $\begin{array}{l}\text { B2B relationship } \\
\text { management }\end{array}$ & $\begin{array}{l}\text { B2B relationship } \\
\text { management }\end{array}$ & & \\
\hline Content marketing & Content marketing & Content marketing & \\
\hline Product & Product & Product & \\
\hline \multicolumn{4}{|l|}{ Reliability } \\
\hline & Baners & & \\
\hline Reputation & Reputation & & \\
\hline \multicolumn{4}{|l|}{ Segmentation types } \\
\hline \multirow[t]{3}{*}{$\begin{array}{l}\text { Augmented reality } \\
\text { technologies usage in } \\
\text { marketing }\end{array}$} & $\begin{array}{l}\text { Augmented reality } \\
\text { technologies usage in } \\
\text { marketing }\end{array}$ & $\begin{array}{l}\text { Augmented reality } \\
\text { technologies usage in } \\
\text { marketing }\end{array}$ & $\begin{array}{l}\text { Augmented reality } \\
\text { technologies usage in } \\
\text { marketing }\end{array}$ \\
\hline & E. payments & & \\
\hline & Sales channels & & \\
\hline
\end{tabular}

The dimensions of environment, behaviour, efficiency assessment and models exhibit the properties of all of 4 channels where the major difference is being in the dimensions of the technology and e-strategy. The characteristics of the communication channel are applicable to dimensions of tools and technology, whereas the properties of the channel of customer relationship management are applicable to the e-strategy dimension, as it includes the strategic aspects of customer relationship, while the characteristics of customer relationship management itself are attributed to the communication channel. 


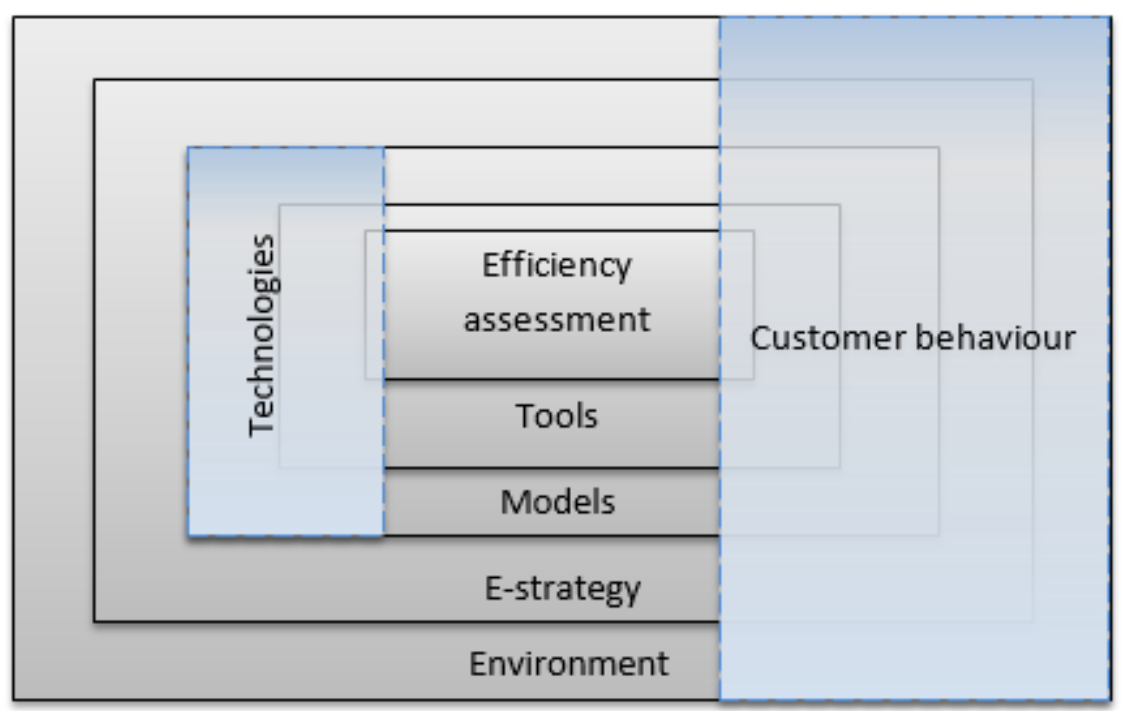

Figure 1 - Completed projects data

The conducted research has shown that scientific studies of tools and technologies have intensified. The results of the research show that various scientists had been actively working on the impact of feedback, technology management, and electronic payments. Upon the emergence of the new Generation $\mathrm{Z}$ of consumers, the consumers' habits as well as their behaviour in e-space have changed significantly, which has led to the formation of a negative aspect - e-fraud. The option of leaving feedback is one of the preventive measures against efraud as well as one of the forms of communication in the customer to customer (C2C) model. The reactions to a transaction and the expression of the emotional experiences in a form of a review serve for improvement of the e-consumer service. The studies in this field give the ability to determine the impact of the reviews, either negative or positive, of their amount, completeness, availability on a consumer's decision to buy and the possibilities of integration of the reviews in the process of improvement of quality of a product or service. The studies of the tools offer the improvements not only of the channel of communication with consumers, but may become an additional channel for transactions, often by making use of the benefits offered by IT.

Along with the changing needs of consumers, new marketing tools emerge. Their successful application depends on the research in the field of adoption of the technologies. The dimension of technology also includes the research of the design of a web page (research of the key elements, their location, format and other preferencies), which require an extremely thorough examination, as an e-consumer is improving his/her skills rapidly and tends to give preference to web pages oriented to satisfaction of his/her needs [11].

One of the most important dimensions is efficiency assessment. Its research leads to the selection of the IM solutions, the further application of the e-strategy or the development of a new strategy. In the e-space, the flow of visitors is particularly important, for the analysis of which the studies of the visitor data are being used. In the assessment of the efficiency of the e-marketing, the studies on the impact of the IM on the activities of an enterprise, allowing to anticipate the aspects of formation of the e-strategy, have been identified as important ones.

The studies involving the behavioural dimension are attributable to the fields requiring the most in-depth research. The needs of the new generation of consumers are changing very dynamically, a systemic and comprehensive examination of the behaviour of the consumers is 
required to be able to adjust to them. This dimension of the studies includes impact of the IM on the behaviour of consumers, aspects of segmentation and shopping habits.

Special attention is also needed for the studies of environmental dimension, as the practical application of the IM tools is strongly dependent on the legal and political aspects. The studies of this dimension also include the studies the IM of the aspects of ecology, impact of the IT on consumers, nationality-based characteristics of business in e-space, nationalitydependent characteristics of behaviour in the e-space and the structure of the market.

The studies of the e-strategy dimension are related to the studies of the dimension of the tools and environment, thus during active research of these particular dimensions, the studies are conducted in this field. General fields of research of e-strategy, brand strategy are noteworthy.

The research in the field of the model dimension is rather inactive. The activity in this field is determined by the new technological possibilities, which enable the parties to interact in new ways and sell products using the new transaction and distribution channels. However, in general, such studies are attributable more to the fields of dimensions of the tools and technologies.

It was found that the formerly proposed categories of research of the IM are incapable of reflecting the basic purpose of the IM, thus the 3-channel classification (transaction channel, distribution channel and communication channel), supplemented by the channel of customer relationship management, is to be considered as appropriate. The said 4 channels are attributable to 7 IM dimensions identified during the research (tools, efficiency assessment, technology, behaviour, models, e-strategy, and environment).

Although the IM is affected by many factors, the consumer behaviour and technologies, which require continuous research, could be considered as the most important of them.

Conclusions from this research and prospects for further developments in this area.

1. The analysis of the concepts of the IM leads to a conclusion that the variety used for defining the conception of the marketing based on the information technologies is basically used to define the process itself. The following definition of the IM concept was chosen to use in the article: the IM means the application of IT in the interaction with the customers in the virtual environment for the organisation's marketing purposes. Main features which were taken for the course of the research were identified (4 channels which revealing the substance of the IM: communication, transaction, distribution and management of relations with customers).

2. Previously processed analysis of the studies in the field of the IM was carried out. Several aspects such as evaluation based on time, analysis of different methodologies of the research in this field were taken as basic research branches. After comparative study the priorities of different stages have been identified: the research of the IM functions, environment applications were relevant in the period 1987 to 2000; the research of the consumer behaviour, e-strategy, communication, branding, pricing, political and legal aspects became relevant in the period of 2000 to 2004. In the period of 2004 to 2013 the emphasis went on the research of tools, technologies, strategy, behaviour, environment. After comparative analysis conclusion to run additional research were newest information and reasoned scientific publications will be taken into account.

3. Research of 128 publications in the field of IM have been processed using the stratified sample, assuming that the fields of research of the IM should be sufficiently homogeneous in each stratum. In the study were encompassed the fields of research of the information technologies and information systems, economics, business management and 
marketing, communication and innovation. The results of first stage analysis were grouped into 7 basic dimensions: customer behaviour, efficiency assessment, models, tools, technologies, e-strategy and environment. The attention should be drawn on the fact, that customer behaviour is common feature which appears in all other dimensions, but also can found separate research field. At the same time the dimension of technologies is common feature which appears in such dimensions as efficiency assessment, models, tool, but also should be analysed as separate on. The fields of the IM where more in-depth studies are needed are the following: research of consumer behaviour, research of new upcoming tools and efficiency assessment.

4. Limitations of this research is that new and potentially upcoming research trends are not identified, so continuously studies are required.

1. Powers T, Advincula D, Austin MS, Graiko S. 2013. Digital and Social Media in the PurchaseDecision Process: A Special Report from the Advertising Research Foundation. J. Advert. Res. 52:479. 2. Sharma A, Sheth JN. 2004. Web-based marketing. J. Bus. Res. 57:696-702.

3. Taylor DG, Strutton D. 2010. Has e-marketing come of age? Modeling historical influences on post-adoption era Internet consumer behaviors. J. Bus. Res. 63:950-956.

4. Tiago MT, Tiago F. 2012. Revisiting the Impact of Integrated Internet Marketing on Firms' Online Performance: European Evidences. Procedia Technol. 5:418-426.

5. Crocker D. 2006. Email history. The living Internet. [cited 14 October 2015]. Available from http://debian.fmi.uni-sofia.bg/ group1_2008/english/email_history.doc.

6. Kiang MY, Raghu T., Shang KH-M. 2000. Marketing on the Internet - who can benefit from an online marketing approach? Decis. Support Syst. 27:383-393.

7. Kiang MY, Raghu TS, Shang KH-M. 2000. Marketing on the Internet - who can benefit from an online marketing approach? Decis. Support Syst. 27:383-393.

8. Ngai EWT. 2003. Internet marketing research (1987-2000): a literature review and classification. Eur. J. Mark. 37:24-49.

9. Schibrowsky JA, Peltier JW, Nill A. 2007. The state of internet marketing research: A review of the literature and future research directions. Eur. J. Mark. 41:722-733.

10. Davidavičienė V, Sabaitytė J. 2014. Tyrimų internetinès rinkodaros srityje analizè. Verslas Teor. ir Prakt. [cited 8 December 2015]. Available from http://www.ceeol.com/aspx/getdocument. aspx ?logid=5\&id=e7cf2f13e070430ca0810cab1a6e97a5.

11. Kwan ISY, Fong J, Wong HK. 2005. An e-customer behavior model with online analytical mining for internet marketing planning. Decis. Support Syst. 41:189-204. 
Д. Сабайтіте, д-р екон. наук,викладач кафедри бізнес-технологій та підприсмництва, Вільнюського технічного університету імені Гедимінаса (Вільнюс, Литва)

В. Давідавічене, д-р екон. наук, професор, завідувач кафедри бізнес-технологій та підприємництва Вільнюського технічного університету імені Гедимінаса (Вільнюс, Литва)

\section{Аналіз інтернет-маркетингових наукових напрямів}

Сталий розвиток інтернет-маркетингу (пізніше позначений як IM) стикається 3 динамічним середовищем і його змінами, які відбуваються як в комерційних умовах, так $і$ у використанні електронних інструментів і концепцій, які застосовуються. Зростаюче значення IM пояснюється розвитком електронних ринків, збільшенням числа споживачів нового покоління, поглибленням інтересу вчених з різних наукових областей, а також розширенням бази знань, яка з ними пов'язана. Незважаючи на постійно зростаючу кількість наукової літератури про маркетинг в Інтернеті, ия область досліджень все ще перебуває на початковій стадії. Мета цієї статті - проаналізувати області поточних ІМ-досліджень $i$ визначити області, необхідні для більш глибокого вивчення. Використовувалися наступні методи: порівняльний аналіз $і$ узагальнення наукової літератури, методи порівняння інформачії, угруповування і графічної інформачії.

Ключові слова: інтернет-маркетинг, інтернет-маркетингове середовище, комунікації, інтернет-маркетингові дослідження.

Received to the editor January 12, 2018 